Agnieszka Ogrodnik-Kalita

\title{
ODRZUCENIE W IMIENIU DZIECKA SPADKU, KTÓREGO PASYWA WYCZERPUJĄ LUB PRZEWYŻSZAJĄ WARTOŚĆ AKTYWÓW. UWAGI NA TLE UCHWAŁY SĄDU NAJWYŻSZEGO Z 22 MAJA 2018 R., III CZP 102/17
}

\section{UWAGI OGÓLNE}

W rozważaniach na temat zakresu prawa cywilnego i przynależności prawa rodzinnego do tej gałęzi prawa podkreśla się ścisły związek tego ostatniego z prawem spadkowym ${ }^{1}$. Bliskie relacje pomiędzy tymi działami prawa cywilnego potwierdza również uchwała z 22 maja 2018 r., w której Sąd Najwyższy stwierdził, że „złożenie przez rodziców w imieniu małoletniego dziecka oświadczenia o odrzuceniu spadku jest czynnością przekraczającą zakres zwykłego zarządu majątkiem dziecka”2. Wskazane orzeczenie stwarza nieczęstą okazję do podjęcia rozważań dotyczących władzy rodzicielskiej, opartych właśnie na rozstrzygnięciu

1 Zob. np. R. ZEGADŁo, Czy polskie prawo zapewnia wystarczająca ochronę prawna małżonka po śmierci współmałżonka, [w:] Księga jubileuszowa Profesora Tadeusza Smyczyńskiego, red. M. Andrzejewski, L. Kociucki, M. ŁĄczKowskA, A.N. Schultz, Toruń 2008, s. 436; A. wolter, J. Ignatowicz, K. Stefaniuk, Prawo cywilne. Zarys części ogólnej, Warszawa 2018, s. 34.

2 Uchwała SN z 22 maja 2018 r., III CZP 102/17. Tak również m.in. postanowienie SN z 15 lipca 2005 r., IV CK 20/05, «OSNC»6/2006, poz. 106; postanowienie SN z 28 maja 2015 r., III CSK 352/14. 
Sądu Najwyższego. Wymusza dokładną analizę krótkiego i ogólnie sformułowanego art. 101 kodeksu rodzinnego i opiekuńczego ${ }^{3}$, będącego normatywną podstawą sprawowania przez rodziców zarządu majątkiem dziecka.

W ramach zagadnienia prawnego będącego przyczyną rozbieżności w wykładni prawa Sądowi Najwyższemu zostały przedstawione trzy pytania. Przedmiotem pierwszego była sama kwalifikacja odrzucenia spadku w imieniu dziecka jako czynności przekraczającej zwykły zarząd jego majątkiem, w sytuacji, w której pasywa wyczerpują lub przewyższają wartość aktywów. Drugie pytanie dotyczyło wpływu złożenia przez rodziców dziecka wniosku do sądu o zezwolenie na złożenie stosownego oświadczenia na bieg terminu określonego w art. $1015 \$ 1$ kodeksu cywilnego ${ }^{4}$, zaś ostatnie tego, na czym ten ewentualny wpływ polega. Potrzeba udzielenia odpowiedzi na drugie pytanie zależała oczywiście od pozytywnej odpowiedzi na pytanie pierwsze.

Uchwała wzbudziła zainteresowanie w piśmiennictwie, co pośrednio świadczy o wadze analizowanej w niej problematyki. Należy jednak zauważyć, że dotychczasowe rozważania na jej temat skupiały się przede wszystkim na samym biegu terminu do złożenia oświadczenia o odrzuceniu spadku. Analizując orzeczenie, nie można oprzeć się wrażeniu, że także w rozważaniach Sądu Najwyższego to ta kwestia odegrała pierwszorzędną rolę, zaś odpowiedź na pierwsze, zasadnicze pytanie nie została dogłębnie uargumentowana. Stanowisko Sądu Najwyższego, zaliczające przedmiotowe oświadczenie do czynności przekraczających zakres zwykłego zarządu majątkiem dziecka, zostało w piśmiennictwie bądź potraktowane jako niebudzące wątpliwości i zasługujące na pełną aprobatę $e^{5}$ bądź poddane krótkiej analizie, prowadzącej do tego samego

3 Ustawa z 25 lutego 1964 r. - Kodeks rodzinny i opiekuńczy (tekst jedn. Dz. U. z 2020 r. poz. 1359).

4 Ustawa z 23 kwietnia 1964 r. - Kodeks cywilny (tekst jedn. Dz. U. z 2020 r. poz. 1740 ze zm.).

T. JustyŃski, Rodzicielskie oświadczenie o przyjęciu lub odrzuceniu spadku a termin zawity $z$ art. 1015 k.c. Glosa do uchwały składu siedmiu sędziów Sądu Najwyższego - Izba Cywilna z dnia 22 maja 2018 r., III CZP 102/17, «Orzecznictwo Sądów Polskich» 3/2020, s. 21. 
wniosku' ${ }^{6}$. Wydaje się jednak, że głębsze pochylenie się nad samym charakterem czynności zarządu majątkiem dziecka, polegającej na odrzuceniu spadku w jego imieniu, może doprowadzić do rezultatów zgoła odmiennych w zakresie jej kwalifikacji i to właśnie do tego problemu zostaną ograniczone rozważania zawarte w niniejszym opracowaniu.

Warto zaznaczyć, że nie do końca słuszne jest stwierdzenie, zgodnie z którym w literaturze powszechnie przyjmuje się, że dla odrzucenia spadku w imieniu dziecka konieczne jest uprzednie zezwolenie sądu opiekuńczego czy że teza ta „nie jest kontestowana w piśmiennictwie”7. Na problem odrzucenia spadku w imieniu dziecka w sytuacji, w której pasywa wyczerpują lub przewyższają wartość aktywów, zwracano uwagę w doktrynie zarówno przed $^{8}$, jak i po podjęciu tej problematyki przez Sąd Najwyższy we wskazanej uchwale 9 .

\section{OdRZUCENIE SPADKU W IMIENIU DZIECKA} JAKO CZYNNOŚĆ ZARZĄDU JEGO MAJĄTKIEM

Nie ulega wątpliwości potrzeba określenia orientacyjnego katalogu czynności przekraczających zwykły zarząd majątkiem dziecka. Wynika ona chociażby z surowej sankcji, z której zastosowaniem wiąże się dokonanie przez rodziców takiej czynności bez zezwolenia sądu

6 M. Rzewuska, Glosa do uchwały SN (7) z dnia 22 maja 2018 r., III CZP 102/17, «Studia Prawnoustrojowe» 42/2018, s. 471-473.

A. PARTYк, Zrzeczenie się dziedziczenia wywierające skutki w stosunku do małoletniego - uwagi de lege ferenda, «Ius Novum» 3/2019, s. 266; T. JusTyŃsKi, op. cit., s. 22.

8 Zob. np. J. SŁYK, Orzekanie w sprawach o zezwolenie na dokonanie czynności przekraczającej zakres zwykłego zarzadu majątkiem dziecka, «Prawo w Działaniu. Sprawy Cywilne» 21/2015, s. 241. E. HolewińskA-Łapińska, Prawo rodzinne $i$ opiekuńcze, [w:] Studia i analizy Sądu Najwyższego. Przegląd orzecznictwa za rok 2018, red. J. Kosonoga, Warszawa 2019, s. 156.

9 P. Czuвıк, Refleksja na temat potrzeby przyjęcia de lege ferenda przepisów wyłączających czynność odrzucenia spadku imieniem małoletniego z kręu czynności przekraczających zakres zwykłego zarządu majątkiem, "Nowy Przegląd Notarialny» 76.3/2018, s. 5-12. 
opiekuńczego. Pozytywnie należy więc ocenić dostrzeżenie wątpliwości w tym zakresie przez Sąd Najwyższy i zajęcie się tą problematyką.

Zasadnicze dla prowadzonych rozważań znaczenie ma rozróżnienie czynności zarządu majątkiem dziecka na czynności zwykłego zarządu i przekraczające ten zarząd. Podział ten jest traktowany jako aksjologicznie uzasadniony i zgodny z zasadą dobra dziecka ${ }^{10}$. Kluczową rolę odgrywają tutaj kryteria pozwalające na dokonanie takiego rozróżnienia. Ich analiza ma bowiem podstawowe znaczenie także dla określenia charakteru odrzucenia spadku, którego pasywa przewyższają lub wyczerpują wartość aktywów.

Już na wstępie należy podkreślić, że przepisy dotyczące zarządu cudzym lub wspólnym majątkiem są oparte na różnych założeniach legislacyjnych, co wyklucza możliwość ustalenia jednolitego kryterium dla określenia istoty i zasięgu czynności zwykłego zarządu, i tym samym czynności przekraczających ten zarząd ${ }^{11}$. Nie do końca więc aktualne dla zarządu majątkiem dziecka będą rozważania prowadzone na gruncie przepisów dotyczących zarządu rzeczą wspólną przy współwłasności w częściach ułamkowych czy zarządu majątkiem wspólnym małżonków. Nie bez znaczenia pozostaje fakt traktowania zarządu majątkiem dziecka jako jednego $z$ atrybutów władzy rodzicielskiej, obok pieczy nad osobą dziecka i jego reprezentacji12. Nawet jeśli konieczność uzyskania zezwolenia sądu na dokonanie czynności przekraczającej ramy zwykłego zarządu traktować jako normatywny wyjątek od zasady samodzielności działania, czyli autonomii rodziców ${ }^{13}$, normy art. $101 \$ 3$ k.r.o. nie można interpretować w oderwaniu od uniwersalnych założeń dotyczących

10 J.M. ŁUKASIEWICZ, Zarząd środkami o szczególnym przeznaczeniu w zakresie zarządu majątkiem dziecka, [w:] Prawo rodzinne i spadkowe wobec współczesnych zjawisk technologicznych i społecznych, red. J.M. ŁukAsiewicz, M. ZaŁucki, Toruń 2018, s. 161.

11 A. Kunicki, Pojęcie zwykłego zarzadu w prawie rodzinnym i opiekuńczym, «RPEiS» 3/1968, s. 111; R. ZEGADŁO, Zarząd majątkiem dziecka, «Monitor Prawniczy» $18 / 2005$, s. 881.

12 Zob. na ten temat: J. STrzebinczyк, Władza rodzicielska, [w:] System prawa prywatnego. Prawo rodzinne i opiekuńcze, XII, red. T. SMYCZyński, Warszawa 2011, s. 293; IDEM, Prawo rodzinne, Warszawa 2013, s. 267.

13 J. Strzebinczy , Prawo rodzinne..., s. 267. 
istoty władzy rodzicielskiej, wśród których w tym kontekście na czoło będzie wysuwać się zaufanie ustawodawcy do rodziców. Rodzice również w zakresie zarządu majątkiem dziecka korzystają z tej autonomii ${ }^{14}$, choć w bardziej ograniczonym zakresie niż w przypadku osobowych elementów władzy rodzicielskiej. Wydaje się także, że w przypadku zarządu majątkiem dziecka występująca tutaj kontrola sądu nie wyłącza zaufania do rodziców ${ }^{15}$ sprawujących władzę rodzicielską, ale jest jego dopełnieniem, koniecznym z punktu widzenia ochrony dobra dziecka.

W związku z tym kryteria pozwalające na określenie spraw przekraczających zakres zwykłego zarządu powinny uwzględniać takie elementy, które odzwierciedlają cel władzy rodzicielskiej ${ }^{16}$. Jako miernik oceny wskazuje się względy obiektywne, jak ciężar gatunkowy konkretnej czynności i jej skutki w sferze majątku dziecka ${ }^{17}$. Podkreśla się również, że czynności prawne rozporządzające i zobowiązujące, prowadzące do uszczuplenia substancji majątku dziecka, ustanowienia ograniczonych praw rzeczowych na nieruchomości, zmieniające przeznaczenie nieruchomości ${ }^{18}$ czy poważnie angażujące zasoby majątku

14 J. Marciniak (Treść i sprawowanie opieki nad małoletnim, Warszawa 1975, s. 80), rozważając problematykę zarządu majątkiem małoletniego, pozostającego pod opieką, jako jedno z kryteriów o charakterze podmiotowym, pozwalające na zaliczenie danej czynności do przekraczających zakres zwykłego zarządu, wskazuje odpowiedni zakres samodzielności opiekuna. Autor podkreśla, że zbyt daleko idące skrępowanie samodzielności opiekuna, przejawiające się w poddaniu drobnych spraw kontroli sądu opiekuńczego, utrudniałoby wykonywanie jego obowiązków i tym samym byłoby sprzeczne z dobrem dziecka. Spostrzeżenie to pozostaje aktualne w kontekście zarządu sprawowanego przez rodziców w ramach władzy rodzicielskiej.

15 Szczególne zaufanie, jakim obdarzono rodziców, wykonujących zarząd majątkiem dziecka, podkreśla T. SoкоŁowsкi (Władza rodzicielska nad dorastajacym dzieckiem, Poznań 1987, s. 133). Natomiast T. Smyczyński (Prawo rodzinne i opiekuńcze, Warszawa 2018, s. 265) wskazuje, że „w odniesieniu do ochrony majątku dziecka nie wystarcza zwykłe zaufanie do rodziców sprawujących władzę rodzicielską, lecz konieczna jest kontrola sądu".

16 Tak w kontekście opieki: J. MARCINIAK, op. cit., s. 80.

17 Wyrok SN z 16 listopada 1982 r., I CR 234/82, «Lex» nr 8486. A. KunICKI, op. cit., s. 117; H. CiepŁA, Zarząd majątkiem dziecka, «Rodzina i Prawo» 20-21/2012, s. 39.

18 A. Kunicki, op. cit., s. 117; A. Zieliński, Piecza nad majątkiem osoby poddanej opiece, «Palestra» 29.1/1985, s. 21. 
dziecka i niemające cechy „Zwykłości”19 należą do czynności przekraczających zakres zwykłego zarządu. Wśród istotnych czynników wymienia się także wartość przedmiotu majątkowego, którego czynność dotyczy, i wartość majątku dziecka, i wzajemny stosunek tych wartości ${ }^{20}$. Zwraca się ponadto uwagę na to, że do czynności przekraczających zakres zwykłego zarządu należy zaliczyć te, które generują znaczne ryzyko ekonomiczne dla dziecka i nie mogą być scharakteryzowane jako rutynowe ${ }^{21}$. Należy również pamiętać o tym, że u podłoża przepisu art. $101 \$ 3$ k.r.o. leży dobro dziecka i ochrona jego interesów majątkowych ${ }^{22}$. W związku z tym trafnie jako najważniejsze kryterium pozwalające na kwalifikację czynności zarządu majątkiem dziecka wskazuje się właśnie „ocenę ryzyka podjęcia niekorzystnych z punktu widzenia dobra dziecka działań dotyczących jego majątku"23.

Powyższe czynniki, traktowane jako kluczowe przy ocenie charakteru czynności zarządu majątkiem dziecka, nie pozwalają na zaliczenie odrzucenia zadłużonego spadku do czynności przekraczających zwykły zarząd. Należy pamiętać, że zadaniem Sądu Najwyższego i przedmiotem rozważań jest szczególny przypadek tej czynności, w którym pasywa przewyższają lub wyczerpują wartość aktywów. Ciężar gatunkowy tej konkretnej czynności jest jedynie prima facie ogromny. Do takich wniosków prowadzi ocena skutków w sferze majątku dziecka. Odrzucenie spadku w tym przypadku nie

19 J. Winiarz, Prawo rodzinne, Warszawa 1994, s. 221.

20 B. Dobrzański, [w:] Kodeks rodzinny i opiekuńczy. Komentarz, red. B. DoBRZAŃski, J. IgNATowiCZ, Warszawa 1975, s. 676.

21 P. BodyŁ-Szymala, Małoletni posiadaczem rachunku bankowego, «Prawo Bankowe» 1/2005, s. 72. J. GAJDA (Komentarz do art. 101 kro, [w:] Kodeks rodzinny i opiekuńczy. Komentarz, red. K. Pietrzyкowski, Warszawa 2018, SIP LEGALIS) zauważa, że art. 101 k.r.o. nie opiera się na formalnym podziale z punktu widzenia konstrukcji prawnej, lecz na tym, czy dana czynność wywiera poważniejszy efekt gospodarczy. W związku z tym pojęcie czynności przekraczającej zwykły zarząd nie pokrywa się z pojęciem czynności rozporządzających i zobowiązujących.

22 A. Zieliński, op. cit., s. 21; J. Ignatowicz, M. NaZAR, Prawo rodzinne, Warszawa 2016, s. 522.

23 J. SŁYK, Orzekanie w sprawach..., s. 198. Zob. również T. SMYCZYŃski, op. cit., s. 265. 
prowadzi do uszczuplenia substancji tego majątku. Jeśli spadkobiercom, którzy odziedziczyli spadek przeciążony długami, zdecydowanie zaleca się odrzucenie spadku ${ }^{24}$, trudno odnaleźć motywy rzeczywiście przemawiające za koniecznością uzyskania zezwolenia sądu przez rodziców w takim wypadku. Jak zauważa Andrzej Kallaus, „nie można znaleźć głębszego uzasadnienia dla pozyskania czegoś, co nie ma żadnej wartości" 25 . Idąc dalej, można stwierdzić, że trudno dopatrzyć się uzasadnienia dla konieczności uzyskania zezwolenia sądu na odrzucenie czegoś, co nie ma żadnej wartości, a nawet przedstawia wartość ujemną. Jeżeli chodzi o wartość przedmiotu majątkowego, którego czynność dotyczy, to nie można zapominać, że w rozważanych przypadkach ta wartość jest równa zeru bądź ujemna.

Należy również zauważyć, że zgodnie z art. 101 k.r.o. rodzice nie mogą bez zezwolenia sądu opiekuńczego dokonywać czynności przekraczających zakres zwykłego zarządu ani wyrażać zgody na dokonywanie takich czynności przez dziecko. Warto podkreślić, że nie został tutaj wyraźnie wskazany podział czynności zarządu majątkiem dziecka na czynności zwykłego zarządu i przekraczające zwykły zarząd, chociaż występuje on w innych regulacjach. W przepisach dotyczących współwłasności można znaleźć zarówno odniesienie do czynności przekraczających zwykły zarząd (art. 199 k.c.), jak i do czynności zwykłego zarządu (art. 201 k.c.). Podobnie uregulował ustawodawca problematykę rodzajów pełnomocnictwa (art. 98 k.c.).

Warto więc zastanowić się, czy jest to celowy zabieg ustawodawcy, czy jedynie odmienne językowo ujęcie w zasadzie podobnych merytorycznie zagadnień. Być może ustawodawca chciał podkreślić jednak zasadę samodzielności rodziców w wykonywaniu zarządu majątkiem dziecka, czy szerzej - w sprawowaniu władzy rodzicielskiej i wyjątkowy

24 Tak bezpośrednio w kontekście odrzucenia spadku w imieniu dziecka zob.: D. CELIŃski, Oświadczenie o przyjęciu lub odrzuceniu spadku złożone przed notariuszem, «Nowy Przegląd Notarialny» 61.3/2014, s. 28. Zob. również np. P. Ksı̨̨żak, Prawo spadkowe, Warszawa 2017, s. 317; G. GorCzyński, [w:] Kodeks cywilny. Komentarz, VI: Spadki (art. 922-1087), red. M. Habdas, M. Fras, Warszawa 2019, s. 536.

25 A. Kallaus, Zezwolenie na odrzucenie spadku przypadajacego osobie małoletniej, «Przegląd Sądowy» 7-8/2016, s. 117. 
charakter konieczności uzyskania zezwolenia sądu opiekuńczego. $\mathrm{Na}$ pewną samodzielność rodziców w tym zakresie zwrócił również uwagę Sąd Najwyższy w jednym ze starszych orzeczeń, podkreślając, że złożenie wniosku o zezwolenie na dokonanie czynności przekraczającej zwykły zarząd majątkiem dziecka jest „wynikiem oceny przez rodziców dziecka potrzeby wystąpienia o to zezwolenie, a nie ustawowego obowiązku w tym zakresie - wystąpienia do sądu opiekuńczego w każdym przypadku, gdy tylko zachodzi możliwość podjęcia danej czynności prawnej, bez względu na ocenę tej potrzeby" ${ }^{26}$. Ciążący na rodzicach wymóg maksymalnej ostrożności przy wykonywaniu zarządu majątkiem dziecka ${ }^{27}$ raczej wzmacnia, a nie osłabia przyjęte stanowisko. W tym kontekście aktualne pozostaje stwierdzenie, zgodnie z którym ochrona majątku dziecka uzależniona jest od prawnej „wrażliwości” rodzica $^{28}$, świadomego, że nie może działać na szkodę interesu majątkowego małoletniego.

Należy też zauważyć, że działanie na szkodę dziecka poprzez odrzucenie spadku, którego przyjęcie byłoby dla jego majątku bardziej korzystne, wydaje się mało prawdopodobne $\mathrm{z}$ jeszcze jednego powodu. Majątek dziecka służy w szerszej perspektywie nie tylko samemu dziecku. Czysty dochód $z$ tego majątku powinien być przede wszystkim przeznaczany - zgodnie z art. 103 k.r.o. - na utrzymanie i wychowanie dziecka oraz jego rodzeństwa, które wychowuje się razem z nim, nadwyżka zaś na inne uzasadnione potrzeby rodziny ${ }^{29}$.

Argument stabilności orzecznictwa, podniesiony w uzasadnieniu swojego stanowiska przez Sąd Najwyższy, niejako kłóci się z konstrukcją przewidzianą w art. 101 k.r.o., która jednak w założeniu miała cechować

26 Uchwała SN z 18 września 1984 r., III CZP 57/84.

27 T. SoкоŁowsкi, Komentarz do art. 101 Kodeksu rodzinnego i opiekuńczego, [w:] Kodeks rodzinny i opiekuńczy. Komentarz, red. H. Dolecki, T. SокоŁOwsкI, «SIP Lex».

28 Tak zob. na temat ochrony środków pieniężnych dziecka: J.M. ŁukAsıEwicz, Ochrona środków pieniężnych dziecka, [w:] Aksjologia prawa cywilnego i cywilnoprawna ochrona dóbr, red. J. Pisuliński, J. ZAWADZKA, Warszawa 2020, s. 263.

29 A. Sylwestrzak (Zarząd dochodami z majątku dziecka, «RPEiS» 80.4/2018, s. 172) zauważa, że art. 103 k.r.o. wprowadza gradację celów, na które ma być przeznaczany dochód z majątku dziecka. 
się elastycznością ${ }^{30}$. O ile, jak już wskazywano, potrzeba stworzenia orientacyjnego katalogu czynności przekraczających zakres zwykłego zarządu majątkiem dziecka nie ulega wątpliwości, o tyle nie może on służyć celom sprzecznym $\mathrm{z}$ istotą i intencjami leżącymi u podstaw podziału tych czynności na dwie kategorie ${ }^{31}$.

Tak jak już wskazywano na wstępie rozważań, pogląd przeciwny do wyrażonego w analizowanej uchwale nie jest do końca odosobniony. Pogłębioną argumentację przemawiającą za przyjęciem, że odrzucenie spadku w przypadku, w którym aktywa przewyższają pasywa, nie przekracza granic zwykłego zarządu, przedstawia Jerzy Słyk. Autor trafnie podkreśla, że jeżeli aprobowany jest pogląd, zgodnie z którym czynności o charakterze wyłącznie przysparzającym traktowane są jako czynności zwykłego zarządu majątkiem dziecka, „to tym bardziej czynność prowadząca do usunięcia ryzyka ponoszenia konsekwencji nabycia spadku składającego się z długów powinna zostać zaklasyfikowana w ten sposób" 32 . Słyk zwraca ponadto uwagę na niewielki stopień zagrożenia interesów dziecka w przypadku dopuszczenia dokonywania przez rodziców odrzucenia spadku w jego imieniu bez zezwolenia sądu opiekuńczego $^{33}$. Podkreślając wynikającą z art. $101 \$ 3$ k.r.o. elastyczność oceny czynności zarządu majątkiem dziecka, zauważa, że ustawodawca celowo zrezygnował z wskazania czynności przekraczających zwykły zarząd w sposób kazuistyczny i w związku z tym brak jest podstaw do uznania, że odrzucenie spadku w każdym przypadku do nich należy ${ }^{34}$.

\footnotetext{
$30 \quad$ J. SŁY K, Orzekanie w sprawach..., s. 241.
}

31 Nie do końca jasne wydaje się pytanie P. Czubika (op. cit., s. 8) o zasadność utrzymywania w prawie polskim obowiązującej konstrukcji art. $101 \$ 3$ k.r.o. i ewentualne zmiany przepisów w tym zakresie. Interwencja ustawodawcy jest tutaj zbędna i może budzić wątpliwości z punktu widzenia zasad prawidłowej legislacji. Trudno dopatrzyć się konieczności wyłączenia spod zakresu zastosowania art. 101 k.r.o. odrzucenia spadku, w przypadkach, w których pasywa przewyższają aktywa, jeśli samo odrzucenie spadku nie jest wskazane w tym przepisie.

32 J. SŁY K, Orzekanie w sprawach..., s. 199. Zob. również J. SŁY K, [w:] Komentarze Prawa Prywatnego, V: Kodeks rodzinny i opiekuńczy. Komentarz, red. K. Osajda, Warszawa 2017, s. 1262.

33 J. SŁY K, Orzekanie w sprawach..., s. 241.

34 Ibidem. 
Na ten aspekt problemu zwraca także uwagę Bartosz Kucia, uwypuklając znaczenie okoliczności konkretnego przypadku dla oceny pod tym kątem czynności zarządu ${ }^{35}$. Zdaniem autora taka metoda interpretacji sprzyja uproszczeniu obrotu prawnego. Dzieje się tak zwłaszcza w sytuacjach niebudzących wątpliwości z uwagi na nieznaczną wartość spadku ${ }^{36}$. Elżbieta Holewińska-Łapińska dodaje, że możliwość odrzucenia spadku nabrała $\mathrm{w}$ ostatnich latach istotnego znaczenia $\mathrm{z}$ uwagi na zadłużenie wielu osób fizycznych ${ }^{37}$. Autorka wskazuje również, że odrzucenie spadku, którego pasywa wyczerpują lub przewyższają wartość aktywów, wydaje się zgodne z dobrem dziecka i jako takie powinno być traktowane jako czynność zwykłego zarządu ${ }^{38}$.

\section{FUNKCJE SANKCJI BEZWZGLĘDNEJ NIEWAŻNOŚCI CZYNNOŚCI ZARZĄDU MAJĄTKIEM DZIECKA A ODRZUCENIE SPADKU W JEGO IMIENIU}

Nie bez znaczenia dla prowadzonych rozważań pozostają skutki złożenia przez rodziców oświadczenia o odrzuceniu spadku bez uprzedniego zezwolenia sądu opiekuńczego, w przypadku przyjęcia za Sądem Najwyższym, że stanowi ono czynność przekraczającą zwykły zarząd majątkiem dziecka. Oświadczenie takie jest bezwzględnie nieważne ${ }^{39}$.

35 B. Kucia, Oświadczenie o przyjęciu lub odrzuceniu spadku w imieniu małoletniego, [w:] Prawo prywatne wobec wyzwań współczesności. Księga pamiątkowa dedykowana Profesorowi Leszkowi Ogiegle, red. M. Fras, P. ŚlęZAK, Warszawa 2017, s. 225.

36 Ibidem.

37 E. HolEWIŃSKA-ŁAPIŃSKA, op. cit., s. 156.

38 Ibidem.

39 Tak wprost: uchwała SN z 24 czerwca 1961 r., 1 CO 16/61. O skutkach braku zezwolenia sądu opiekuńczego zob. np.: P. ReICHel, Treść i forma oświadczenia o przyjęciu lub odrzuceniu spadku, «Rejent» 23.9/2013, s. 76; J. STrzebinczy , Prawo rodzinne, s. 267; A. Kallaus, Udział osoby małoletniej w postępowaniu opiekuńczym, Poznań 2015, s. 18; IDEM, Zezwolenie na odrzucenie..., s. 115; J. IGNATOwiCz, M. NAZAR, op. cit.; H. CiepŁA, Zarzą majątkiem dziecka w praktyce i w orzecznictwie, [w:] Człowiek - Prawo - Państwo. Księga jubileuszowa dedykowana Stanisławowi Leszkowi Stadniczeńko, red. W. ŻyŁко, Warszawa 2017, s. 194; B. Kucı, Oświadczenie o przyjęciu lub odrzuceniu 
Przewidziana jest więc tutaj najostrzejsza sankcja dla wadliwych czynności prawnych, polegająca na tym, że mimo istnienia zewnętrznych pozorów konkretnej czynności prawnej, nie wywołuje ona zamierzonych skutków prawnych ${ }^{40}$.

Bez wątpienia w przypadku braku uzyskania zezwolenia sądu na czynność przekraczającą zwykły zarząd majątkiem dziecka sankcja bezwzględnej nieważności czynności prawnej pełni funkcję ochronną. Konieczność uzyskania zezwolenia sądu w takich przypadkach chroni dobro dziecka w aspekcie materialnym. Dla przykładu bezwzględnie nieważna będzie umowa sprzedaży nieruchomości wchodzącej w skład majątku dziecka, zawarta bez uprzedniego zezwolenia sądu opiekuńczego. Oznacza to, że wskazana umowa nie wywołała zamierzonych skutków prawnych ${ }^{41}$, co zgodnie z intencją ustawodawcy chroni majątek dziecka przed uszczupleniem, w przypadku, w którym czynność nie została wcześniej oceniona przez sąd pod kątem jej zgodności z dobrem dziecka. Można również stwierdzić, że wskazana sankcja pełni funkcję dezaprobującą wobec zachowania rodziców, którzy dokonują czynności prawnej, nie dopełniając wszystkich wymaganych prawem przesłanek jej ważności ${ }^{42}$.

Zgoła odmiennie sytuacja będzie się kształtowała w przypadku odrzucenia spadku, którego pasywa wyczerpują lub przewyższają wartość aktywów. Warto głębiej przyjrzeć się analizowanemu zagadnieniu pod kątem sankcji bezwzględnej nieważności, gdyż wnioski mogą okazać się

spadku w imieniu małoletniego, [w:] Prawo prywatne wobec wyzwań współczesności. Księga pamiątkowa dedykowana Profesorowi Leszkowi Ogiegle, red. M. FRAS, P. ŚLĘZAK, Warszawa 2017, s. 222; T. SMYCZyŃski, op. cit., s. 266; J. GAJDA, Dobra wiara w znaczeniu obiektywnym na gruncie unormowań Kodeksu rodzinnego i opiekuńczego, Toruń 2020, s. 176. Warto zauważyć, że sankcja jest tutaj bardziej rygorystyczna niż przy czynnościach zarządu majątkiem wspólnym, do których wymagana jest zgoda drugiego małżonka. A. Kunicki, op. cit., s. 113.

40 Z. Radwański, A. Olejniczak, Prawo cywilne - część ogólna, Warszawa 2017, s. 362; A. Wolter, J. Ignatowicz, K. Stefaniuk, op. cit., s. 416.

41 Zob. A. Wolter, J. Ignatowicz, K. Stefaniuk, op. cit., s. 416.

${ }^{42}$ O funkcji ochronnej i sankcji nieważności jako wyrazu etycznej dezaprobaty ustawodawcy w kontekście pozorności jako wady oświadczenia woli zob. M. WILEJCZYк, Zagadnienia etyczne części ogólnej prawa cywilnego, Warszawa 2014, s. 311. 
dosyć zaskakujące. Przyjęcie, że odrzucenie pasywnego spadku w imieniu dziecka jest czynnością przekraczającą zwykły zarząd, pociąga za sobą skutek w postaci bezwzględnej nieważności takiej czynności, jeśli została dokonana bez zezwolenia sądu. W takim przypadku znajdzie zastosowanie art. $1015 \$ 2$ k.c. i nastąpi przyjęcie przez dziecko spadku z dobrodziejstwem inwentarza, oczywiście przy założeniu, że upłynęło sześć miesięcy od dnia, w którym przedstawiciel ustawowy dziecka dowiedział się o tytule powołania dziecka do spadku. Bezwzględną nieważność oświadczenia o odrzuceniu spadku należy bowiem potraktować jednoznacznie z brakiem takiego oświadczenia. Przyjęcie spadku z dobrodziejstwem inwentarza, chociaż z ograniczeniem odpowiedzialności za długi, wiąże się, jak podkreślił Sąd Najwyższy w uzasadnieniu analizowanej uchwały, z koniecznością sporządzenia inwentarza spadku oraz $z$ ewentualnymi sporami z wierzycielami spadkodawcy i ze związanymi z tym kosztami ${ }^{43}$. Należy pamiętać o tym, że chodzi przecież o odrzucenie spadku, którego pasywa wyczerpują lub przewyższają wartość aktywów, a bycie spadkobiercą zadłużonego spadku pociąga za sobą wiele niedogodności ${ }^{44}$. Osiągnięcie efektu w postaci ograniczonej odpowiedzialności wymaga od spadkobierców określo-

43 Zob. na ten temat również P. DzIEnIs, Wpływ przyjęcia spadku z dobrodziejstwem inwentarza na przebieg egzekucji sądowej, «Białostockie Studia Prawnicze» 22.4/2017, s. 72. Jak zaznaczył Sąd Najwyższy w postanowieniu z 28 maja 2015 r., (III CSK 352/14): „nawet złagodzona forma odpowiedzialności spadkobiercy za długi spadkowe wiąże się dla niego z licznymi trudnościami i niedogodnościami; w grę wchodzi konieczność sporządzenia spisu inwentarza, konieczność przedsięwzięcia różnych czynności faktycznych i prawnych dotyczących majątku spadkowego, uczestnictwa spadkobiercy w postępowaniach sądowych lub administracyjnych dotyczących spadku”.

${ }_{44}$ Jak podkreśla G. Gorczyński: „przede wszystkim przyjęcie spadku z dobrodziejstwem inwentarza jest dopiero pierwszym krokiem, który musi poczynić spadkobierca, który chce ograniczyć swoją odpowiedzialność za długi spadkowe. Aby osiągnąć efekt w postaci ograniczenia odpowiedzialności, konieczne są dalsze kroki, w tym zwykle: podniesienie «zarzutu» ograniczonej odpowiedzialności, sporządzenie wykazu inwentarza lub zainicjowanie sporządzenia spisu inwentarza, w razie większej liczby spadkobierców także dokonanie działu spadku”. G. Gorczyński, [w:] Kodeks cywilny. Komentarz, VI: Spadki (art. 922-1087), red. M. Habdas, M. Fras, Warszawa 2019, s. 536. Oczywiście wskazanych czynności w analizowanym wypadku będą musieli dokonywać rodzice jako przedstawiciele ustawowi dziecka. 
nej aktywności ${ }^{45}$. Czas poświęcony na tę „aktywność” przez rodziców będzie oczywiście czasem, który nie będzie mógł zostać poświęcony dziecku. Grzegorz Gorczyński podkreśla, jak złożonym problemem jest urzeczywistnienie ograniczonej odpowiedzialności spadkobierców za długi spadkowe, wymieniając okoliczności, które nawet w przypadku odpowiedzialności za długi spadkowe $\mathrm{z}$ dobrodziejstwem inwentarza sprawiają, że spadkobiercy nie mogą „spać spokojnie" ${ }^{\text {"46 }}$. Ochrona dziecka wynikająca z ograniczonej odpowiedzialności za długi spadkowe jest więc $\mathrm{w}$ istocie jedynie pozorna ${ }^{47}$. Fikcja przyjęcia spadku $\mathrm{z}$ dobrodziejstwem inwentarza może stanowić swoistą pułapkę dla dziecka. Prawo nie powinno zaś stanowić pułapki dla podmiotów, których sytuację reguluje - tym bardziej jeśli chodzi o osoby małoletnie ${ }^{48}$. Bartłomiej Swaczyna, w kontekście upływu terminu do odrzucenia spadku i jego skutków, zaznacza, że w odniesieniu do spadku, którego wartość jest ujemna, przyjęcie spadku z dobrodziejstwem inwentarza „nie ma żadnego racjonalnego uzasadnienia" i rozwiązanie to pociąga za sobą niekiedy istotny uszczerbek majątkowy po stronie spadkobiercy ${ }^{49}$. Autor

45 G. Gorczy Ński, O ograniczonej odpowiedzialności spadkobierców, czyli skoro miało być tak dobrze, dlaczego jest tak źle?, [w:] Egzekucja z majątku spadkowego. Ograniczona i nieograniczona odpowiedzialność za długi spadkowe, red. M. ZAŁUCKI, Warszawa 2016, s. 140.

46 Ibidem.

47 A. Kallaus podkreśla jednak, zwracając w szczególności uwagę na regulację art. 1032 k.c., że ustawodawca zapewnił osobie małoletniej bardzo dogodne warunki dziedziczenia w razie bezczynności jej przedstawicieli ustawowych. A. Kallaus, Zezwolenie na odrzucenie..., s. 119.

48 B. Kucia, op. cit., s. 220.

49 B. Swaczyna, Odrzucenie spadku nabytego przez dziecko, [w:] Rozprawy cywilistyczne. Księga pamiątkowa dedykowana Profesorowi Edwardowi Drozdowi, red. M. PECyna, J. Pisuliński, M. Podrecka, Warszawa 2013, «SIP Lex». W tym kontekście aktualne pozostaje zdanie M. Matczaka ('Summa iniuria'. O błędzie formalizmu w stosowaniu prawa, Warszawa 2007, s. 9-10), wyrażone w kontekście formalizmu prawniczego. Stwierdzenie, że w analizowanych sprawach mamy do czynienia $z$ formalizmem w stosowaniu prawa, jest pewnym uproszczeniem, biorąc pod uwagę to, że koncepcja stosowania prawa zwana formalizmem, najogólniej rzecz ujmując, „polega na stosowaniu prawa ściśle według zapisów tekstu prawnego, nawet wtedy gdy osiągane rozstrzygnięcie jest niesprawiedliwe lub sprzeczne ze zdrowym rozsądkiem”. Autor 
dosadnie zauważa, że w takich przypadkach następuje przyjęcie spadku „Z przekleństwem inwentarza”50.

Zastosowanie sankcji bezwzględnej nieważności nie spełnia więc tutaj roli, którą powinno pełnić w przypadku czynności przekraczających zwykły zarząd majątkiem dziecka ${ }^{51}$. Sytuacja dziecka, czyli tego podmiotu, którego interesy podlegają ochronie w ramach przepisów o zarządzie majątkiem dziecka, jest gorsza w wyniku zastosowania tej sankcji niż w przypadku, w którym dokonana czynność zarządu byłaby ważna. Należy przecież pamiętać o tym, że fikcja zawarta w art. 1015 k.c. rodzi daleko idące skutki, prowadząc do nabycia spadku przez osobę, która jest do niego powołana „bez względu na jej wolę i rzeczywiste intencje" 52 . Przyjęcie przez dziecko spadku, chociaż z dobrodziejstwem inwentarza, będzie w takim przypadku mimowolne i ta mimowolność będzie oznaczała właśnie przyjęcie spadku wbrew woli rodziców. Odrzucenie spadku dokonane bez zezwolenia sądu jasno dowodzi istnienia

zwraca jednak uwagę na problem, z którym spotykają się osoby, kontaktujące się z sądami czy urzędami, doznające zawodu związanego ze „specyficzną, formalistyczną racjonalnością działania tego typu instytucji. Zawód ten jest wynikiem frustracji, którą przeżywamy, kiedy rozstrzygnięcie w naszej sprawie wydaje się zupełnie sprzeczne ze zdrowym rozsądkiem". Oczywiście w przypadku postępowania w sprawie zezwolenia na złożenie oświadczenia o odrzuceniu pasywnego spadku w imieniu dziecka nie samo rozstrzygnięcie może się wydawać sprzeczne ze zdrowym rozsądkiem, ale sama konieczność przeprowadzenia postępowania w tej sprawie. Na ten problem zwraca pośrednio uwagę także B. Kucia (op. cit., s. 223), podkreślając, że jednokierunkowe rozwiązanie, polegające na kwalifikacji odrzucenia spadku jako czynności przekraczającej zwykły zarząd majątkiem dziecka, nie zawsze pozostaje zbieżne z potrzebami obrotu prawnego „ocenianymi również z punktu widzenia spadkobierców i doniosłości przedsiębranych czynności”.

50 B. Swaczyna, op. cit.

51 J. SŁYк (Orzekanie w sprawach..., s. 241) zauważa, że generalnie „sankcja bezwzględnej nieważności może nie gwarantować ochrony interesów dziecka, nawet w przypadku dokonania niekorzystnej dla niego czynności przekraczającej zakres zwykłego zarządu, np. z uwagi na stosowanie przepisów o ochronie dobrej wiary osób trzecich czy skutki upływu czasu".

52 W. Borysiak, [w:] Komentarze Prawa Prywatnego. Kodeks cywilny. Komentarz. Spadki, red. K. OsajDA, Warszawa 2019, s. 1011. 
po ich stronie woli odrzucenia spadku w imieniu dziecka ${ }^{53}$. Nikt zaś nie powinien być „zmuszony” do nabycia spadku, nawet z dobrodziejstwem inwentarza, wbrew swej oczywistej i manifestowanej woli ${ }^{54}$.

\section{STARANNOŚĆ ZAWODOWA NOTARIUSZA PRZY SPORZĄDZANIU OŚWIADCZEŃ SPADKOWYCH A OCHRONA DOBRA DZIECKA}

Przy odpowiedzi na pytanie, czy możliwe jest zapewnienie wystarczającego stopnia ochrony interesu majątkowego dziecka przy odrzuceniu spadku w jego imieniu dokonywanego bez zezwolenia sądu opiekuńczego, nie można pomijać regulacji art. $1018 \$ 3$ k.c. Zgodnie z tym przepisem wskazane oświadczenie składa się przed sądem lub przed notariuszem. Doniosłość prawna oświadczenia spadkowego spowodowała więc sformalizowanie tej czynności ${ }^{55}$. Warto więc zastanowić się, w jakim stopniu ta formalna strona składanego oświadczenia jest gwarancją ochrony dobra dziecka.

Zgodnie $z$ art. $80 \$ 2$ i 3 prawa o notariacie ${ }^{56}$ na notariuszu ciąży obowiązek czuwania nad należytym zabezpieczeniem praw i słusznych interesów stron oraz innych osób, dla których czynność ta może powodować skutki prawne, a także udzielania stronom niezbędnych wyjaśnień dotyczących dokonywanej czynności notarialnej. Obowiązki te są określane jako „zawodowy komplementarny obowiązek udzielania przez notariusza wyjaśnień i informacji" ${ }^{\text {"7 }}$. Obowiązek wyjaśniająco-doradczy może być traktowany jako etap wstępny realizacji zabezpieczenia praw

53 Zob. w kontekście udzielenia przez sąd zezwolenia na odrzucenie spadku po upływie terminu: T. JAsIAKIEWICZ, W poszukiwaniu środków ochrony prawnej małoletniego spadkobiercy przed mimowolnym przyjęciem spadku, «RPEiS» 71.4/2019, s. 125.

54 Postanowienie SN z 28 maja 2015 r., III CSK 352/14.

55 P. ReICHEL, op. cit., s. 69.

56 Ustawa z 14 lutego 1991 r. - Prawo o notariacie (tekst jedn. Dz. U. z 2020 r. poz. 1192 ze zm.).

57 A. Oleszko, Staranność zawodowa notariusza $w$ świetle art. 80 prawa o notariacie, «Rejent» 7.9/1997, s. 9. 
i słusznych interesów stron ${ }^{58}$. Zabezpieczenie praw i słusznych interesów przejawia się w starannym zapoznaniu się ze sprawą, ponieważ może się zdarzyć, że czynność, której strony chcą dokonać, jest z nimi sprzeczna ${ }^{59}$. Zachowanie szczególnej staranności przez notariusza obejmuje zatem nie tylko konieczność sporządzenia aktu notarialnego zgodnie z wymogami formalnymi, lecz także obowiązek oceny prawa materialnego ${ }^{60}$.

Odnosząc powyższe uwagi do odrzucenia spadku w imieniu dziecka, należy podkreślić, że obowiązkiem notariusza jest wyjaśnienie przedstawicielowi ustawowemu skutków złożenia takiego oświadczenia. Podkreśla się, że szczególnej staranności od notariusza wymaga dokumentowanie oświadczeń o przyjęciu lub odrzuceniu spadku z udziałem osób małoletnich ${ }^{61}$. Konieczne jest zaznaczenie w sposób wyraźny, ale jednocześnie zrozumiały dla rodzica i adekwatny do jego poziomu świadomości prawnej, że skutkiem odrzucenia spadku w imieniu dziecka będzie utrata praw i obowiązków wchodzących w jego skład ${ }^{62}$. Ważne jest również rozpoznanie przez notariusza oczekiwań stron, związanych

58 A. Ż̇BA, Słuszność jako wartość w pracy notariusza, «Studia Iuridica Lubliniensa» 25.2/2016, s. 261.

59 T. SAdowski, Odpowiedzialność cywilna notariusza, «Rejent» 5.5/1995, s. 77.

60 M. SeKuŁa-Leleno, Granice obowiązku informacyjnego notariusza przy sporządzaniu aktu notarialnego - glosa do wyroku Sądu Najwyższego z dnia 28 czerwca 2019 r. (IV CSK 224/18), «Ius Novum» 3/2020, s. 218.

${ }^{61}$ J. BAREJ, H. ZBRzeżNA-CĄKAŁA, Uwagi dotyczące dokumentowania oświadczeń o przyjęciu lub odrzuceniu spadku bądź też zapisu windykacyjnego $w$ świetle analiz zespołu wizytacyjnego, «Nowy Przegląd Notarialny» 71.1/2017, s. 8.

62 O skutkach złożenia oświadczenia o odrzuceniu spadku zob. np. E. Skow RoŃSKa-Bocian, Odpowiedzialność za długi spadkowe. Komentarz, Warszawa 2018, s. 79; W. Borysiak, [w:] Komentarze Prawa Prywatnego, IVa: Kodeks cywilny. Komentarz. Spadki, red. K. Osajda, Warszawa 2019, s. 989. A. Sylwestrzak (Rola kierownika urzędu stanu cywilnego przy uznaniu ojcostwa, [w:] Kodeks rodzinny i opiekuńczy po nowelizacji, red. J. MAZURKIEW ICZ, Warszawa 2010, s. 123) w kontekście obowiązków kierownika urzędu stanu cywilnego przy uznaniu ojcostwa wskazuje, że „wyjaśnienie obejmuje przekazanie jakichś informacji innej osobie w taki sposób, aby informacje te były dla niej zrozumiałe, jasne. Jest więc czymś więcej niż samym tylko poinformowaniem, skoro obejmuje także skutek w postaci stania się tych informacji jasnymi dla odbiorcy". 
z dokonywaną czynnością notarialną ${ }^{63}$. Notariusz powinien również podkreślić, jak bardzo daleko idące skutki wywoła złożenie oświadczenia i nie mieć żadnych wątpliwości co do zamiaru zniweczenia powołania do spadku ${ }^{64}$. Jest obowiązany pouczyć strony, jaką doniosłość prawną i ekonomiczną ma dokonywana czynność notarialna ${ }^{65}$. Pomimo tego, że w doktrynie zaznacza się, że chociaż motywy, dla których składane są poszczególne rodzaje oświadczeń spadkowych, są prawnie nieistotne, notariusz powinien w miarę możliwości poznać intencje osób, które chcą uregulować swoją sytuację prawną do spadku, gdyż spadkobierca nie zawsze potrafi przewidzieć skutki złożonego oświadczenia i wyrazić zamiar, jaki chce osiągnąć ${ }^{66}$. Należy zauważyć, że w pracy notariusza nie bez znaczenia jest aspekt psychologiczny, który powinien przejawiać się w nawiązaniu z klientem bliższego kontaktu, pozwalającego na uzyskanie istotnych informacji ${ }^{67}$. Wskazany pozajurydyczny aspekt wydaje się szczególnie ważny w sprawach rodzinnych. Tak jak w przypadku każdego spadkobiercy, również w przypadku rodziców składających oświadczenie w imieniu dziecka podjęcie decyzji o odrzuceniu spadku jest uwarunkowane wieloma istotnymi czynnikami ${ }^{68}$. To właśnie ustalenie przez notariusza rzeczywistego motywu, kierującego decyzją rodziców o odrzuceniu spadku, może mieć kluczowe znaczenie z punktu widzenia ochrony dobra dziecka i oceny pod tym kątem składanego oświadczenia $^{69}$. Przemysław Biernacki wprost zaznacza, że „obowiązek

63 A. Oleszko, Podstawy i przesłanki odpowiedzialności cywilnej notariusza, «Rejent» 2.7-8/1992, s. 35.

64 E. Skowrońska-Bocian, J. Wierciński, [w:] Kodeks cywilny. Komentarz, IV: Spadki, red. J. Gudowski, Warszawa 2017, s. 308. Zob. również T. SADowski, op. cit., s. 82 .

65 A. Oleszko, Staranność zawodowa..., s. 16.

66 G. GorczyŃsKi, [w:] Kodeks cywilny..., s. 536.

67 A. Oleszko, Staranność zawodowa..., s. 11.

68 Zob. E. Lewandowska, Oświadczenie o odrzuceniu spadku, «Studia Prawnoustrojowe» 24/2014, s. 86.

${ }^{69}$ O motywach przemawiających za składaniem poszczególnych rodzajów oświadczeń spadkowych zob. np. E. LEWANDowsKa, op. cit., s. 86; E. SKOWrońsKA-Bocian, Odpowiedzialność za długi spadkowe. Komentarz, Warszawa 2018, s. 24; G. GorczyńsKI, Komentarz..., s. 536. W tym kontekście wydaje się zasadne rozróżnienie dwóch 
czuwania nad dobrem dziecka spoczywa niewątpliwie również na notariuszu, jako funkcjonariuszu publicznym, wykonującym zawód zaufania publicznego. Notariusz powinien zatem odmówić dokonania czynności prawnej, która byłaby sprzeczna $\mathrm{z}$ dobrem dziecka"70.

Oczywiście może pojawić się w tym kontekście zarzut, że przecież argument dotyczący roli notariusza i jego obowiązków mógłby zostać podniesiony również w kontekście innych czynności zarządu majątkiem dziecka, które są traktowane jako przekraczające granice zwykłego zarządu i wymagają dla swej ważności formy aktu notarialnego (np. przeniesienia własności nieruchomości, stanowiącej składnik majątku dziecka). Należy jednak pamiętać o innych motywach - wskazanych wyżej - które przemawiają za zaliczeniem odrzucenia spadku w imieniu dziecka do czynności zwykłego zarządu. Zakres i granice obowiązku informacyjnego notariusza powołane racje wzmacniają i przemawiają za przyjęciem tezy o wystarczającym stopniu ochrony interesów dziecka przy dokonywaniu tej czynności, nawet bez konieczności uzyskania uprzedniego zezwolenia sądu opiekuńczego. Złożenie oświadczenia o odrzuceniu spadku, przedstawiającego wartość dodatnią, byłoby bezwzględnie nieważne ${ }^{71}$ jako czynność przekraczająca zwykły zarząd majątkiem dziecka. W takim przypadku sankcja bezwzględnej nieważności

przypadków, oparte na kolejności dziedziczenia, które będą w większym lub mniejszym stopniu determinowały stopień ostrożności notariusza. Inaczej kształtuje się sytuacja w tych przypadkach, w których dziecko zostaje powołane do spadku w pierwszej kolejności, odmiennie zaś gdy dochodzi do dziedziczenia w wyniku odrzucenia spadku przez spadkobierców, dziedziczących w bliższej kolejności. Ten pierwszy przypadek będzie miał miejsce dla przykładu przy dziedziczeniu ustawowym w przypadku rozwodu rodziców i niewstąpienia w związek małżeński przez rodzica - spadkodawcę. Sam rodzic jako osoba spoza kręgu spadkobierców ustawowych oczywiście nie ma tutaj uprawnienia do przyjęcia bądź odrzucenia spadku, więc jego decyzja w tym zakresie nie będzie tutaj żadną wskazówką co do składu spadku. W sytuacji drugiej, gdzie wskutek odrzucenia przez rodzica spadku, np. po dziadku dziecka, w jego miejsce wchodzi małoletnie dziecko, zagrożenie interesów dziecka wydaje się mniej prawdopodobne. Jedynie zupełnie wyjątkowe okoliczności mogą sprawić, że spadkobierca odrzuci spadek w sytuacji, w której jego przyjęcie byłoby bardziej korzystne.

70 P. Biernacki, Dobro dziecka w praktyce notarialnej, «Rejent» 29.9/2019, s. 78.

$71 \quad$ J. SŁY K, Orzekanie w sprawach..., s. 241. 
spełniałaby swoją funkcję ochronną. Jednak biorąc pod uwagę zakres obowiązków notariusza, mało prawdopodobne jest złożenie takiego oświadczenia. To w zakreślonych przepisami prawa granicach jego obowiązków przejawia się zewnętrzna kontrola decyzji rodziców.

\section{ASPEKTY PRAKTYCZNE ODRZUCENIA PRZEZ RODZICÓW ZADŁUŻONEGO SPADKU W IMIENIU DZIECKA}

Warto również zwrócić uwagę na aspekt praktyczny analizowanego zagadnienia. W obecnym stanie prawnym, przy szeroko ujętym kręgu spadkobierców ustawowych ${ }^{72}$, wymóg uzyskania zezwolenia na odrzucenie spadku w imieniu dziecka pociąga za sobą konieczność przeprowadzenia często bardzo dużej liczby postępowań w tym przedmiocie, dotyczących spadku po jednym spadkodawcy. Przecież takie zezwolenie będą musiały uzyskać nie tylko na przykład dzieci spadkodawcy dla odrzucenia spadku w imieniu jego wnuków. Już w sytuacji, w której udział spadkowy przypadnie w wyniku odrzucenia przez powołanych w bliższej kolejności wnukom rodzeństwa spadkodawcy, czyli ich zstępnym, można $\mathrm{z}$ dużą dozą prawdopodobieństwa stwierdzić, że będą to osoby zbliżone wiekiem do wnuków samego spadkodawcy, a więc małoletnie. Z podobnym przypadkiem będziemy mieli do czynienia przy dziedziczeniu zstępnych dziadków spadkodawcy, czyli dzieci kuzynów, gdyż nie mamy tutaj ograniczenia co do stopnia pokrewieństwa. Doprowadzenie do dziedziczenia gminy (Skarbu Państwa) wymaga w obecnym stanie prawnym nierzadko całego ciągu odrzuceń spadku ${ }^{73}$, również w imieniu dziecka. Z badań przeprowadzonych przez J. Słyka wynika,

72 Zob. np. E. Skowrońska-Bocian, Prawo spadkowe, Warszawa 2018, s. 54. Z badań przeprowadzonych przez J. SŁYKA (Orzekanie w sprawach..., s. 220) wynika, że w analizowanych przez autora przypadkach spadek najczęściej przypadał dzieciom wskutek dziedziczenia po dziadkach lub pradziadkach.

73 M. PAZDAN, Zmiany w ukształtowaniu zasad odpowiedzialności za długi spadkowe w prawie polskim, [w:] Ochrona strony słabszej stosunku prawnego. Ksiega jubileuszowa ofiarowana Profesorowi Adamowi Zielińskiemu, red. M. Boratyńska, Warszawa 2016, s. 432 . 
że złożenie w imieniu dziecka oświadczenia o odrzuceniu spadku było zdecydowanie najczęściej występującą kategorią zamierzonej przez rodziców czynności zarządu majątkiem dziecka, na której dokonanie chcieli uzyskać zezwolenie sądu ${ }^{74}$.

W doktrynie podkreśla się, że w przypadku zarządu cudzym majątkiem, czyli na przykład majątkiem dziecka, ryzyko podjęcia czynności niekorzystnej dla osoby reprezentowanej jest mniejsze niż w przypadku zarządu rzeczą wspólną, gdyż sąd czuwa nad działalnością przedstawiciela $^{75}$. Sąd pełni tutaj rolę czynnika doradczego, kontrolującego i w pewnych sprawach decydującego ${ }^{76}$. Należy jednak pamiętać, że taki wniosek będzie uprawniony tylko w sytuacji, w której sąd rzeczywiście będzie pełnił funkcję kontrolną i ochronną względem interesów dziecka. Jak trafnie podkreśla J. Słyk, „nie powinno budzić wątpliwości, że jednym z głównych ustaleń sądu powinno być określenie wartości odziedziczonego spadku"7.$Z$ badań przeprowadzonych przez autora wynika jednak, że sądy co do zasady nie prowadziły postępowania dowodowego, które pozwoliłoby na szczegółowe określenie wartości majątku spadkowego ${ }^{78}$ i najczęściej podejmowały decyzję na podstawie informacji uzyskanych przez rodziców, a także na podstawie faktu odrzucenia spadku przez innych spadkobierców ${ }^{79} . Z$ dokonanej przez autora analizy orzecznictwa wynika również, że tylko w jednej ze zbadanych spraw wartość spadku okazała się dodatnia, co stanowiło $0,8 \%$ liczby spraw poddanych badaniu $^{80}$. Można więc niestety przypuszczać, że nawet w sytuacji, w której rodzice niewłaściwie oszacują wartość spadku i jego odrzucenie nie będzie korzystne, na co zwrócił uwagę Sąd Najwyższy w uzasadnieniu przedmiotowej uchwały, jego rzeczywisty skład i tak w zdecydowanej większości przypadków nie zostanie zweryfikowany w postępowaniu sądowym. W przypadku chęci złożenia przez rodziców oświadczenia

J. SŁY K, Orzekanie w sprawach..., s. 218.

A. Kunicki, op. cit., s. 112.

Ibidem.

J. SŁYк, Orzekanie w sprawach..., s. 221.

Ibidem.

Ibidem, s. 233.

Ibidem, s. 221, 234.
} 
o odrzuceniu takiego spadku przed notariuszem, notariusz może, jak już wskazywano, odmówić dokonania czynności notarialnej, jako sprzecznej z dobrem dziecka i tym samym z prawem. Dla dokonania takiej czynności wymagane jest bowiem zezwolenie sądu opiekuńczego, gdyż wchodzi tutaj w grę najważniejsze kryterium podziału czynności zarządu majątkiem dziecka, jakim jest zagrożenie interesów dziecka i ryzyko podjęcia niekorzystnych działań w tym zakresie.

Bardziej dosadnie problem ten ujmuje Paweł Czubik. Autor zauważa, że postępowania te najczęściej nie mają żadnej wartości merytorycznej, a nierzadko stają się „swoistą parodią postępowania sądowego" ${ }^{81}$, a relacje wnioskodawców i uczestników tego typu postępowań, składających następnie przed notariuszem oświadczenie o odrzuceniu spadku, są „przesycone goryczą i mało pochlebne dla efektywności i powagi wymiaru sprawiedliwości" 82 .

Nie bez znaczenia będą tutaj również koszty postępowania. Na pierwszy rzut oka nikłe, mogą jednak przysporzyć trudności finansowych rodzicom dziecka. Można przypuszczać, że przypadki odrzucenia spadku jednak rzadziej mają miejsce w rodzinach zamożnych. Warto podkreślić, że obecnie opłata stała od wniosku o wszczęcie postępowania nieprocesowego wynosi $100 \mathrm{zł}^{83}$. Na koszty te będzie się składała również taksa notarialna ${ }^{84}$.

81 P. CzUBik, op. cit., s. 6.

82 Ibidem, s. 12. Na marginesie warto zauważyć, że niestety doświadczenie życiowe pozwala przypuszczać, że wynikająca z art. 583 kodeksu postępowania cywilnego konieczność wysłuchania drugiego z rodziców dziecka może być zarzewiem konfliktów pomiędzy małżonkami. Wnioskodawcą w sprawie o zezwolenie na odrzuceniu spadku w imieniu małoletniego będzie zazwyczaj - chociaż oczywiście nie ma takiego wymogu - rodzic spokrewniony ze spadkodawcą, który już wcześniej spadek odrzucił, wymóg wysłuchania będzie więc dotyczył rodzica jedynie z nim spowinowaconego. Nietrudno wyobrazić sobie uwagi ze strony drugiego z rodziców dziecka, dotyczące osoby spadkodawcy np. teścia, jako tego, który „przysparza małżonkom kłopotów nawet po śmierci”.

${ }^{83}$ Art. 23 ustawy z 28 lipca 2005 r. o kosztach sądowych w sprawach cywilnych (tekst jedn. Dz. U. z 2020 r. poz. 755).

${ }^{84} \$ 8$ rozporządzenia Ministra Sprawiedliwości z 28 czerwca 2004 r. w sprawie maksymalnych stawek taksy notarialnej (tekst jedn. Dz. U. z 2018 r. poz. 272). 
Za przyjęciem stanowiska, zgodnie $\mathrm{z}$ którym odrzucenie $\mathrm{w}$ imieniu dziecka pasywnego spadku jednak mieści się w granicach zwykłego zarządu jego majątkiem, przemawia także interes wierzycieli zmarłego spadkodawcy. Konieczność przeprowadzenia postępowania wydłuża przecież stan niepewności co do tego, komu spadek przypadnie, tym bardziej gdy kolejno powołani do spadku spadkobiercy będą spadek odrzucać. Chociaż wskazuje się, że w przypadku kolizji między dobrem małoletniego a interesem osoby trzeciej decydować powinno to pierwsze $^{85}$, wydaje się, że w tym przypadku interes małoletniego, chroniony przez fundamentalną zasadę ochrony dobra dziecka, nie kłóci się $\mathrm{z}$ ochroną praw wierzycieli. Taka konstatacja wynika z założenia, zgodnie z którym odrzucenie spadku bez zezwolenia sądu opiekuńczego nie godzi w dobro dziecka i tym samym przeprowadzenie postępowania $\mathrm{w}$ tym przedmiocie nie jest obligatoryjnym elementem ochrony jego interesu. Podkreśla się, że dobro dziecka niewątpliwie powinno być punktem wyjścia dla oceny konkretnej czynności, lecz dobro to nie może zepchnąć na zbyt daleki plan interesu osób trzecich ${ }^{86}$. W przypadku odrzucenia spadku w imieniu dziecka nietrudno znaleźć kompromis w tym zakresie.

\section{UWAGI KOŃCOWE}

Będąca podstawą powyższych rozważań uchwała Sądu Najwyższego jest bezsprzecznie jednym z ważniejszych orzeczeń ostatnich lat dotyczących zarządu majątkiem dziecka. Analizując jej uzasadnienie, nie można jednak oprzeć się wrażeniu, że jako podstawowy problem Sąd Najwyższy potraktował kwestię biegu terminu do złożenia oświadczenia o odrzuceniu spadku w imieniu dziecka, a samą kwalifikację tej czynności z punktu widzenia art. 101 k.r.o. uznał za raczej oczywistą i tym samym drugorzędną. Szkoda, że nie rozwinięto rozważań w tym zakresie, ponieważ tutaj, wbrew pozorom, tkwi rzeczywista wątpliwość.

85 J. Marciniak, op. cit., s. 80.

${ }^{86}$ A. Kunicki, op. cit., s. 117. 
Oczywiście uchwałę można ocenić pozytywnie, biorąc pod uwagę intencje Sądu Najwyższego i dążenie do jak najpełniejszej ochrony interesów dziecka. Poddane powyższej analizie zagadnienia pozwalają jednak na przyjęcie stanowiska odmiennego, zgodnie z którym odrzucenie spadku w imieniu dziecka, w sytuacji, w której pasywa wyczerpują lub przewyższają wartość aktywów, może być traktowane jak czynność zwykłego zarządu majątkiem dziecka i nie będzie to pociągało za sobą zagrożenia jego dobra. Wskazane przez Sąd Najwyższy rozwiązanie, w kontekście wskazanych problemów praktycznych, wydaje się również zbyt idealistyczne. Pewne problemy w działaniu wymiaru sprawiedliwości nie mogą być argumentem o zasadniczym znaczeniu, w szczególności jeśli chodzi o dobro dziecka, ale w przypadkach, w których jednak trudno dopatrzyć się jego zagrożenia, mogą dodatkowo wzmacniać przyjęte stanowisko.

ODRZUCENIE W IMIENIU DZIECKA SPADKU, KTÓREGO PASYWA WYCZERPUJĄ LUB PRZEWYŻSZAJĄ WARTOŚĆ AKTYWÓW. UWAGI NA TLE UCHWAŁY SĄDU NAJWYŻSZEgo Z 22 MAJA 2018 R., III CZP 102/17

\section{Streszczenie}

Przedmiotem rozważań jest uchwała Sądu Najwyższego z 22 maja 2018 r., III CZP 102/17, w której stwierdzono, że „złożenie przez rodziców w imieniu małoletniego dziecka oświadczenia o odrzuceniu spadku jest czynnością przekraczającą zakres zwykłego zarządu majątkiem dziecka”. Autorka poddaje analizie odrzucenie spadku w imieniu dziecka jako czynność zarządu jego majątkiem, wskazując na kryteria podziału na czynności zwykłego zarządu i przekraczające ten zarząd. Zauważa, że wskazywane w tym kontekście w doktrynie i orzecznictwie czynniki nie pozwalają na zaliczenie odrzucenia zadłużonego spadku do czynności przekraczających ten zarząd. Wskazuje ponadto na skutki złożenia oświadczenia o odrzuceniu spadku w imieniu dziecka bez zezwolenia sądu opiekuńczego, poddając krytycznej analizie funkcje sankcji bezwzględnej nieważności dla ochrony dobra dziecka w tych przypadkach. Istotnym zagadnieniem są rozważania poświęcone zadaniom i roli 
notariusza przy dokumentowaniu oświadczenia o odrzuceniu spadku w imieniu dziecka.

Rejection of an Inheritance on Behalf of a Child When the Liabilities of the Estate are Equal to or ExCEed its Assets: Comments in the ConteXt of Resolution No. III CZP 102/17 Passed by the Polish Supreme Court on 22 May 2018

\section{Summary}

This paper discusses Resolution No. III CZP 102/17 passed by the Supreme Court of the Republic of Poland on 22 May 2018, which states that "the rejection of an inheritance by the parents of a child who is a minor is an act which exceeds the scope of the ordinary management of the child's property." I examine the rejection of an inheritance on behalf of a child as an act which is part of the management of the child's property, describing the criteria determining which aspects of such a rejection are ordinary acts of management, and which aspects are acts exceeding ordinary management. I observe that the factors mentioned in the legal doctrine and in the jurisprudence relating to such cases do not allow us to classify a decision to refuse to inherit an estate with outstanding debts as an act exceeding the scope of ordinary management. I describe what happens if the parents submit a declaration rejecting an inheritance on behalf of their child without obtaining the consent of the guardianship court; and I conduct a critical analysis of the part the sanction of absolute invalidity plays in the protection of the child's interests. Another important issue I discuss is the role and duty of the notary who makes a record of a declaration on the rejection of an inheritance on behalf of a child.

Słowa kluczowe: majątek; dziecko; długi; spadek; zezwolenie sądu; notariusz.

Keywords: property; child, debt; the estate of a deceased person; consent of court; notary. 


\section{Literatura}

BAREJ J., ZBRzeŻNA-CąKA£a H., Uwagi dotyczace dokumentowania oświadczeń o przyjęciu lub odrzuceniu spadku bądź też zapisu windykacyjnego w świetle analiz zespołu wizytacyjnego, «Nowy Przegląd Notarialny» 71.1/2017, s. 5-16.

BIERNACKi P., Dobro dziecka w praktyce notarialnej, «Rejent» 28.9/2018, s. 60-80.

BodyŁ-Szymala P., Małoletni posiadaczem rachunku bankowego, "Prawo Bankowe» $1 / 2005$, s. 71-83.

Celiński D., Oświadczenie o przyjęciu lub odrzuceniu spadku złożone przed notariuszem, «Nowy Przegląd Notarialny» 61.3/2014, s. 17-35.

Ciep£A H., Zarząd majątkiem dziecka w praktyce i w orzecznictwie, [w:] Człowiek - Prawo - Państwo. Ksiegga jubileuszowa dedykowana Stanisławowi Leszkowi Stadniczeńko, red. W. ŻyŁKo, Warszawa 2017, s. 191-204.

Ciep£A H., Zarzad majątkiem dziecka, «Rodzina i Prawo» 20-21/2012, s. 33-50.

Czuвiк P., Refleksja na temat potrzeby przyjęcia de lege ferenda przepisów wyłaczajacych czynność odrzucenia spadku imieniem małoletniego z kręgu czynności przekraczających zakres zwykłego zarządu majątkiem, «Nowy Przegląd Notarialny» 76.3/2018, s. 5-12.

DzIENis P., Wplyw przyjęcia spadku $z$ dobrodziejstwem inwentarza na przebieg egzekucji sq̨dowej, «Białostockie Studia Prawnicze» 22.4/2017, s. 71-84.

GaJDA J., Dobra wiara w znaczeniu obiektywnym na gruncie unormowań Kodeksu rodzinnego i opiekuńczego, Toruń 2020.

GorCzyński G., O ograniczonej odpowiedzialności spadkobierców, czyli skoro miało być tak dobrze, dlaczego jest tak źle?, [w:] Egzekucja z majątku spadkowego. Ograniczona i nieograniczona odpowiedzialność za dtugi spadkowe, red. M. ZAŁUCKI, Warszawa 2016, s. 138-153.

Holewińska-Łapińska E., Prawo rodzinne i opiekuńcze, [w:] Studia i analizy Sądu Najwyższego. Przeglad orzecznictwa za rok 2018, red. J. Kosonoga, Warszawa 2019, s. 149-164.

Ignatowicz J., Nazar M., Prawo rodzinne, Warszawa 2016.

JASIAKIEWICZ T., W poszukiwaniu środków ochrony prawnej małoletniego spadkobiercy przed mimowolnym przyjęciem spadku, «RPEiS» 71.4/2019, s. 125-137.

JustyŃsкi T., Rodzicielskie oświadczenie o przyjęciu lub odrzuceniu spadku a termin zawity z art. 1015 k.c. Glosa do uchwały składu siedmiu sędziów Sądu Najwyższego - Izba Cywilna z dnia 22 maja 2018 r., III CZP 102/17, «Orzecznictwo Sądów Polskich» 3/2020, s. 14-22.

Kallaus A., Udział osoby małoletniej w postępowaniu opiekuńczym, Poznań 2015.

Kallaus A., Zezwolenie na odrzucenie spadku przypadajacego osobie małoletniej, «Przegląd Sądowy» 7-8/2016, s. 112-120. 
Kodeks cywilny. Komentarz, IV: Spadki, red. J. Gudowski, Warszawa 2017.

Kodeks cywilny. Komentarz, VI: Spadki (art. 922-1087), red. M. HabDAs, M. Fras, Warszawa 2019.

Kodeks rodzinny i opiekuńczy. Komentarz, red. B. Dobrzański, J. Ignatowicz, Warszawa 1975.

Kodeks rodzinny i opiekuńczy. Komentarz, red. H. Dolecki, T. Soкоєowski, Warszawa 2013.

Komentarze Prawa Prywatnego, IVa: Kodeks cywilny. Komentarz. Spadki, red. K. Osajda, Warszawa 2019.

Komentarze Prawa Prywatnego, V: Kodeks rodzinny i opiekuńczy. Komentarz, red. K. Osajda, Warszawa 2017.

Ksıężak P., Prawo spadkowe, Warszawa 2017.

Kucıa B., Oświadczenie o przyjęciu lub odrzuceniu spadku w imieniu małoletniego, [w:] Prawo prywatne wobec wyzwań współczesności. Księga pamiątkowa dedykowana Profesorowi Leszkowi Ogiegle, red. M. FrAs, P. ŚLĘZAK, Warszawa 2017, s. 219-227.

Kunicki A., Pojęcie zwykłego zarządu w prawie rodzinnym i opiekuńczym, «RPEiS» 3/1968, s. 111-124.

LewAndowska E., Oświadczenie o odrzuceniu spadku, «Studia Prawnoustrojowe» 24/2014, s. 83-95.

ŁUKASIEWICZ J.M., Ochrona środków pieniężnych dziecka, [w:] Aksjologia prawa cywilnego i cywilnoprawna ochrona dóbr, red. J. Pisuliński, J. ZAWADZKA, Warszawa 2020, s. 262-277.

ŁUKASIEWICZ J.M., Zarząd środkami o szczególnym przeznaczeniu $w$ zakresie zarządu majątkiem dziecka, [w:] Prawo rodzinne i spadkowe wobec współczesnych zjawisk technologicznych i społecznych, red. J.M. ŁukAsiEwICZ, M. ZAŁUCKI, Toruń 2018, s. 161-190.

Marciniak J., Treść i sprawowanie opieki nad małoletnim, Warszawa 1975.

Matczaк M., 'Summa Iniuria' - o błędzie formalizmu $w$ stosowaniu prawa, Warszawa 2007.

Oleszko A., Podstawy i przesłanki odpowiedzialności cywilnej notariusza, «Rejent» 2.7-8/1992, s. 28-42.

Oleszko A., Staranność zawodowa notariusza $w$ świetle art. 80 prawa o notariacie, «Rejent» 7.9/1997, s. 9-21.

PARTYк A., Zrzeczenie się dziedziczenia wywierające skutki w stosunku do małoletniego - uwagi de lege ferenda, "Ius Novum» 3/2019, s. 259-279.

PAZDAN M., Zmiany w ukształtowaniu zasad odpowiedzialności za długi spadkowe w prawie polskim, [w:] Ochrona strony słabszej stosunku prawnego. Ksiega 
jubileuszowa ofiarowana Profesorowi Adamowi Zielińskiemu, red. M. BorATYŃsKa, Warszawa 2016, s. 421-432.

Radwański Z., Olejniczak A., Prawo cywilne - część ogólna, Warszawa 2017.

ReICHel P., Treść i forma oświadczenia o przyjęciu lub odrzuceniu spadku, «Rejent» 23.9/2013, s. 62-77.

Rzewuska M., Glosa do uchwały SN (7) z dnia 22 maja 2018 r., III CZP 102/17, «Studia Prawnoustrojowe» 42/2018, s. 469-478.

SAdowski T., Odpowiedzialność cywilna notariusza, «Rejent» 5.5/1995, s. 67-85.

SeKuŁa-Leleno M., Granice obowiązku informacyjnego notariusza przy sporzadzaniu aktu notarialnego - glosa do wyroku Sądu Najwyższego z dnia 28 czerwca 2019 r. (IV CSK 224/18), «Ius Novum» 3/2020, s. 209-226.

Skowrońska-Bocian E., Odpowiedzialność za długi spadkowe. Komentarz, Warszawa 2018.

Skowrońska-Bocian E., Prawo spadkowe, Warszawa 2018.

SŁYK J., Orzekanie w sprawach o zezwolenie na dokonanie czynności przekraczajacej zakres zwykłego zarządu majątkiem dziecka, «Prawo w Działaniu. Sprawy Cywilne» 21/2015, s. 191-243.

Smyczyński T., Prawo rodzinne i opiekuńcze, Warszawa 2018.

Soкоєошsкi T., Władza rodzicielska nad dorastającym dzieckiem, Poznań 1987.

Strzebinczy J., Prawo rodzinne, Warszawa 2013.

Swaczyna B., Odrzucenie spadku nabytego przez dziecko, [w:] Rozprawy cywilistyczne. Ksiega pamiątkowa dedykowana Profesorowi Edwardowi Drozdowi, red. M. Pecyna, J. Pisuliński, M. Podrecka, Warszawa 2013, s. 569-583.

SylwestrzaK A., Rola kierownika urzędu stanu cywilnego przy uznaniu ojcostwa, [w:] Kodeks rodzinny i opiekuńczy po nowelizacji, red. J. MAzUr KIEwICZ, Warszawa 2010, s. 121-131.

Sylwestrzak A., Zarzq̨d dochodami z majątku dziecka, «RPEiS» 70.4/2018, s. 171-184.

System prawa prywatnego. Prawo rodzinne i opiekuńcze, XII, red. T. SMYczyński, Warszawa 2011.

WiLejCzy к M., Zagadnienia etyczne części ogólnej prawa cywilnego, Warszawa 2014. Winiarz J., Prawo rodzinne, Warszawa 1994.

Wolter A., Ignatowicz J., Stefaniuk K., Prawo cywilne. Zarys części ogólnej, Warszawa 2018.

ZegadŁo R., Czy polskie prawo zapewnia wystarczajaca ochrone prawna matżonka po śmierci wspótmatżonka, [w:] Księga jubileuszowa Profesora Tadeusza Smyczyńskiego, red. M. Andrzejewski, L. Kociucki, M. ŁączKowsKa, A.N. Schultz, Toruń 2008, s. 435-449. 
ZegadŁo R., Zarząd majątkiem dziecka, «Monitor Prawniczy» 18/2005, s. 879-886. Zieliński A., Piecza nad majątkiem osoby poddanej opiece, «Palestra» 29.1/1985, s. 18-30.

ŻABA A., Stuszność jako wartość w pracy notariusza, «Studia Iuridica Lubliniensa» 25.2/2016, s. 257-266. 